\title{
Transformações da área-alvo da Operação Urbana Vila Leopoldina-Jaguaré pelo mercado imobiliário: a verticalização residencial como motor de desenvolvimento urbano
}

\author{
Eunice H. Abascal. Universidade Presbiteriana Mackenzie, São Paulo, Brasil \\ Volia Kato. Universidade Presbiteriana Mackenzie, São Paulo, Brasil \\ Raquel Cymrot. Universidade Presbiteriana Mackenzie, São Paulo, Brasil
}

RESUMO | Na cidade contemporânea, o ambiente construído vem se modificando, observando-se a presença de áreas em transformação de uso e esvaziamento. Em São Paulo, a transformação do ambiente construído mediante esse processo, frente à dinâmica de ocupação do solo e reconfiguração de áreas pela via do mercado imobiliário, parece se consagrar como a principal força de produção do espaço urbano, apesar da existência de instrumentos urbanísticos de indução do desenvolvimento da cidade, articulado pela regulação do poder público municipal. Uma intensiva e prioritária produção do espaço urbano, pela mão dos empreendedores imobiliários, vem sendo observada na cidade de São Paulo, revelandose desvinculada, de modo geral, de planos e projetos que poderiam induzir a realização de um espaço urbano planejado e sinérgico. Operações Urbanas (OU) e Operações Urbanas Consorciadas (OUC) são os instrumentos que em tese deveriam produzir uma articulação entre os interesses públicos e privados na produção de uma cidade mais justa e equitativa. $\mathrm{O}$ artigo apresenta uma análise crítica da OUC Vila Leopoldina-Jaguaré, que embora tenha se apresentado como possibilidade de transformação de um perímetro pela via do plano e projeto urbano, jamais foi regulamentada em lei, dando oportunidade a uma ocupação exclusivamente realizada por empreendimentos imobiliários.

PALAVRAS CHAVE | projeto urbano, política urbana, mercado imobiliário

ABSTRACT | Built environment has changed in contemporary cities, and the presence of transformations in uses and emptiness of certain areas. In Sao Paulo, the dynamics of land uses and the reconfiguration of areas by real estate market have proved themselves as the main force of production of urban spaces. This holds true even though urban instruments for the induction of city development, articulated by the regulation of municipal public powers, exist. An intensive and prioritary production of urban space by two real estate entrepreneurs has been observed in the city of Sao Paulo. It reveals itself as, generally, separated from projects and plans that could induce the creation of a planned and synergic urban space. Operações Urbanas (OU) and Operações Urbanas Consorciadas (OUC) that hypothetically should produce an articulation between public and private interests in the production of a fair and equal city. This article presents a critical analysis of such an operation, OUC Vila Leopoldina - Jaguaré, that though presented as a possibility for the transformation of a perimeter through urban planning and projects, was never legally regulated giving opportunity to an occupation exclusively driven by real estate projects.

KEY WORDS | urban project, urban policy, real state market

Recibido el 4 de abril de 2011, aprobado el 28 de septiembre de 2011

E-mail: Eunice H. Abascal, eunicehelena.abascal@mackenzie.br | Volia Kato, volia.kato@mackenzie.br | Raquel Cymrot, raquel.cymrot@ mackenzie.br 


\section{Questôes de partida}

O ambiente construído da cidade contemporânea vem se modificando, com a presença de áreas em transformação de uso e processos de esvaziamento. O fenômeno tem como causa transformaçôes produtivas em curso desde os anos de 1980, acarretando uma nova dinâmica industrial e logística de distribuição de bens, mercadorias e informação, além de impactos da desconcentração de atividades secundárias (Diniz, 1996). Lógicas econômicas que incidem na cidade, e a força de interesses privados vinculados ao mercado, atuam de modo decisivo sobre a valorização do solo, acentuando a especulação imobiliária de modo amplo e em algumas áreas de oportunidade, em um sentido inverso ao caráter social e à qualidade ambiental, inerentes à essência da cidade. Contrapondo-se a este fenômeno que parece inexorável e unidirecional, instrumentos urbanísticos têm sido adotados em diversos países, sobretudo naqueles capazes de expressar consensos sob a forma de plano e projeto urbano, conciliando interesses e valorizando o caráter coletivo da cidade, mediante participação social.

Cabe salientar que o Brasil, com a elaboração do Estatuto da Cidade (Lei Federal $n^{\circ} 10.257 / 2001$ ), foi reconhecido pelos organismos internacionais, em especial nos Fóruns Urbanos Mundiais do UN-Habitat, como o país que se antecipou na elaboração de instrumentos político institucionais inovadores de intervenção urbana. Por meio de mecanismos efetivos de participação social e articulação públicoprivada em projetos urbanos, entre eles, as Operações Urbanas (OU) e Operações Urbanas Consorciadas (OUC) promover-se-ia o desenvolvimento urbano, induzido a partir de planejamento em nível municipal.

No entanto, a transformação do ambiente construído da cidade de São Paulo, a ocupação do solo e a reconfiguração de suas áreas pela via do mercado imobiliário, parecem se consagrar como a principal força de produção do espaço urbano, apesar da existência de instrumentos urbanísticos de indução do desenvolvimento da cidade incorporados pela regulação do poder público municipal.

A questão crítica que este artigo enuncia, assinala uma intensiva e prioritária produção do espaço urbano pelos empreendedores imobiliários, observada hoje em São Paulo, desvinculada ou escassamente induzida por planos e projetos que deveriam intermediar a transformação da cidade de maneira planejada e sinérgica. A prática de mercado que consagra a prioridade de empreendimentos imobiliários, minimiza um possível equilíbrio entre edificação e ambiente urbano, equilíbrio este que poderia ser alcançado pela implementação dos planos propostos para a cidade. Cabe assinalar que a aplicação de instrumentos urbanísticos institucionalizados no Brasil, permitiria balancear interesses privados e coletivos na produção do espaço urbano.

No Brasil, as Operações Urbanas (OU) foram definidas pelo Estatuto da Cidade (Lei Federal no 10.257/2001), como parcerias de natureza público-privadas, cujo efeito fundamenta o desenvolvimento urbano com base no planejamento de nível municipal (Ministério das Cidades, 2009). O conceito de Operação Urbana define a transformação induzida de áreas-alvo, bem como a aplicação de mecanis- 
mos compensatórios a partir de instrumentos urbanísticos, com a finalidade de um possível combate à exclusão e à desigualdade, bem como o enfrentamento de desequilíbrios diversos, ao gerir soluções planejadas para esses problemas.

Desta maneira, as OU enfatizam - como um sistema integrado de intervenções atuando em diversos níveis (social, econômico, territorial e ambiental), o caráter prioritário da regulação pública, submetendo a essa esfera, decisões de variada ordem. Esses instrumentos foram concebidos como meio de regulação pelo poder público, das transformações de uso e configuração do espaço urbano, de que são exemplo as Operações Urbanas (OU) e Operações Urbanas Consorciadas (OUC). Tomando como referência para a análise uma área definida como Operação Urbana pelo Plano Diretor Estratégico do Município de São Paulo (aprovado em 2002) - a região da Vila Leopoldina-Jaguaré, na região oeste da cidade - o artigo aborda o descolamento entre plano e projeto, e a concretização da cidade real por empreendimentos imobiliários que viabilizam a produção de um espaço urbano, que prioriza o domínio privado frente ao público. A defasagem entre a política urbana e a velocidade e intensidade da dinâmica imobiliária nesta área, induz ao surgimento de edifícios enclausurados nos próprios lotes e cujo fechamento estabelece uma marcante dicotomia entre público e privado, voltando as costas à ambiência urbana, que é a expressão dos valores coletivos.

Os instrumentos urbanísticos aqui conceituados como inovadores, nasceram como meios capazes de induzir a transformação de áreas urbanas e fundamentar projetos urbanos, instrumentos para a transformação estrutural de um fragmento, amparada na gestão articulada entre o poder público e a iniciativa privada, articulação que definiria o projeto urbano (Montandon \& Souza, 2007). Esta relação entre instrumentos e projetos, possibilitaria a transformação total do ambiente construído e não a exclusiva realização de empreendimentos imobiliários. Vislumbrava-se, com seu enunciado, a possibilidade de intervir em áreas ou perímetros definidos com base em recursos financeiros, gerados dentro do perímetro-alvo, na forma de contrapartidas destinadas ao poder público e resgatados como direito de exceção dos índices de verticalização previstos pelo Plano Diretor e pela Lei de Zoneamento e Uso do Solo (Castro, 2006). Entretanto, pode-se afirmar que a aplicação desse instrumento apequena-se na forma de uma política reducionista, desvinculada da regulação pública da produção do espaço urbano, de forma a garantir a qualidade total do ambiente e pautada na ação mercadológica, que tem como mote a construção introvertida de produtos imobiliários. A apropriação do território pelo mercado, em face da não implementação ou implementação parcial de projetos urbanos pelo Estado, tem como resultado a morosidade ou esquecimento da requalificação do espaço público e do ambiente construído, recrudescendo práticas que conferem prioridade à realização do capital na forma de ativos imobiliários. Tal recorrência faz emergir um uso que se dá, na verdade, por detrás de grades, em um espaço de "uso coletivo" e para poucos.

Em São Paulo, as Operações Urbanas Consorciadas (OUC) foram introduzidas nos Planos Diretores de 1985, 1988, 1991 e 2002. Consistem em instrumento de transformação da cidade, com potencialidade para fortalecer a relação entre 
plano e projeto urbano e, com base nesse vínculo, garantir ganhos expressivos para o interesse público. Conforme o Estatuto da Cidade, uma Operação Urbana Consorciada implica em definir um perímetro de atuação, proposto de maneira articulada a um programa de ocupação do solo, vinculado ao atendimento econômico e social à população diretamente atingida pelas intervenções. Essa proposta, que articula a transformação do território à regulação de impactos sociais frutos de intervenções no espaço urbano foi enunciada pelo Estatuto da Cidade, para facultar a intervenção do poder público, na forma de planejamento, e sanar eventuais desequilíbrios gentrificadores (Somekh \& Campos, 2005).

A gentrificação é, no marco do capitalismo, a substituição da população residente e de usos antigamente predominantes, como efeito da valorização imobiliária e fundiária a partir de melhorias realizadas ao ambiente construído, sendo os promotores imobiliários os agentes de impulso desse fenômeno (Smith, 2006). A gentrificação, assim definida, acarreta a expulsão de populações residentes das áreas-alvo em que incide e, juntamente com a expansão do tecido urbano e assentamentos que se originam desse movimento, contribui para a dissolução das relações e vínculos desenvolvidos por esses residentes com seu lugar de origem. Este fenômeno e efeitos sociais correlatos poderiam, em tese, serem corrigidos pela aplicação de mecanismos redistributivos dos recursos e contrapartidas financeiras obtidas dentro do perímetro da OU. Tal política redistributiva fundamentada na função social da propriedade - captação de mais-valias produzidas a partir do solo criado (Ribeiro \& Cardoso, 1992) - se constitui em estímulo à permanência de população em áreas beneficiadas por melhorias, estudos de impacto de vizinhança e contrapartidas e instrumentos para a sua obtenção, de que é exemplo, o pagamento de outorga onerosa com base em venda de Certificados de Potencial Adicional do Direito de Construir (Cepac). As Operações Urbanas Consorciadas assegurariam a reaplicação dos recursos captados no perímetro considerado, estimulando que se materializem no território. O controle de possíveis efeitos gentrificadores deve ser exercido pela sociedade civil representada, agente legítimo que deve compartilhar do processo de implementação e de decisões presentes no plano e projeto.

Do exposto, pode-se concluir que consiste em mecanismos (sistemas de concessão de incentivos urbanísticos e obtenção de contrapartidas) que fundamentam projetos urbanos, para concretizar as transformações priorizadas no Plano Diretor. Trata-se de mediação pelo poder público da atuação do mercado imobiliário, abrindo frentes de negociação de índices urbanísticos e regulamentação da edificação, mediante o pagamento das mencionadas contrapartidas. Por essas razões, as OU são mecanismos opostos à livre atuação do mercado imobiliário, movido por dinâmicas de potencialização de lucros e estratégias de manipulação da qualidade do ambiente construído com finalidade individualista, colocando-se como instrumentos de articulação de interesses privados e coletivos, na construção de uma cidade de melhor qualidade ambiental e mais justa.

Essas medidas deveriam ser viabilizadas com a participação da iniciativa privada - proprietários e investidores, bem como moradores e usuários permanentes, com 
o objetivo de articular transformações urbanísticas, melhorias sociais e valorização ambiental. Consiste em estratégia de desenvolvimento integrado do território intraurbano, abrangendo habitação, mobilidade, produção, centralidades e política ambiental, instando à predominância na espacialidade resultante do sentido público e social. As áreas-alvo de Operações Urbanas Consorciadas são perímetros no interior dos quais as transformações de uso e ocupação do solo se orientam por um plano consubstanciado em um projeto urbano integrador e mediador desses múltiplos campos e agentes, conduzindo consensos com os diversos atores envolvidos, inclusive agentes imobiliários, a fim de resultar em um ambiente construído em que prime a qualidade ambiental total.

Entre as Operações Urbanas Consorciadas propostas pelo Plano Diretor Estratégico do Município de São Pauloํㅡㄹ elaborado à luz das diretrizes do Estatuto da Cidade, a OU Vila Leopoldina - Jaguaré, na zona oeste ${ }^{2}$, foi objeto de um plano e projeto urbano resultantes de estudos urbanísticos realizados no âmbito da Secretaria Municipal de Planejamento (Sempla), em 2003. Embora não tenha sido regulamentada, um projeto de lei decorreu de estudos urbanísticos e ambientais da equipe técnica do então Departamento de Projetos Urbanos da SEMPLA que, na ocasião, considerou a Operação Urbana Consorciada um instrumento capaz de implementar esse sistema integrado de ações, contemplando a dimensão urbanística e os interesses do mercado imobiliário e da sociedade. Esta visão sistêmica se evidencia nos princípios e diretrizes que regem a $\mathrm{OU}$ em estudo, ao determinar que esta visasse a "transformações urbanísticas estruturais, melhorias sociais e valorização ambiental" (Prefeitura Municipal De São Paulo, PMSP/Secretaria Municipal de Planejamento, Sempla, 2003, não paginado).

A aplicação desse recurso permitiria o papel de regulador ao Estado, promovendo o desenvolvimento urbano ao alcance do poder municipal, pautado na transformação induzida de áreas estrategicamente delimitadas como objeto de Operação Urbana, e combatendo, assim, a exclusão e a desigualdade. Dessa forma, o Estado poderia resgatar contrapartidas, pagas por empreendedores imobiliários como outorga onerosa, pela exceção dos índices de verticalização permitidos pela lei de zoneamento. Ao propor que nas Operações Urbanas Consorciadas as contrapartidas devam ser aplicadas em melhorias dentro de seus perímetros, caracterizar-se-ia feição progressista do instrumento urbanístico.

\footnotetext{
Prefeitura Municipal de São Paulo - PDE 2002-2012, Lei Municipal nº 13.430 de 2002

Os temas e questões assinalados vêm sendo estudados pela pesquisa "Operações urbanas, entre o poder público e o mercado imobiliário: Conflitos entre plano e realidade", realizada por equipe de pesquisadores da Faculdade de Arquitetura e Urbanismo Mackenzie, São Paulo. A pesquisa teve uma primeira fase (2010-11) apoiada pelo Fundo Mackpesquisa do Instituto Presbiteriano Mackenzie e prossegue com apoio do CNPq (Conselho Nacional de Pesquisa), até agosto de 2012. Tem como objetivo compreender o descolamento e conflitos entre a transformação real do território urbano pelo mercado imobiliário na área-alvo da OUC Vila Leopoldina-Jaguaré (seu objeto), planejada para ser implementada em perímetro localizado na região dos distritos de Vila Leopoldina e Jaguaré, bairros tradicionalmente industriais de São Paulo. O perímetro da Operação Urbana Vila Leopoldina-Jaguaré foi delimitado pelo PDE e abrange área ocupada por antigas indústrias no entorno da Ceagesp (Central de Abastecimento Geral do Estado de São Paulo). Encontra-se sob a gestão da Sub-Prefeitura da Lapa, testemunhando transformaçōes decorrentes da reestruturação produtiva do setor secundário.
} 
O plano jamais deixou, até os dias de hoje, os limites do âmbito técnico-burocrático em que foi concebido, o que se deve, entre outros fatores, à descontinuidade política na esfera de governo municipal, interveniente na continuidade técnica. Após sete anos desde a concepção, plano e projeto urbano não foram implementados e se observa na área-alvo da OUC, a ação edilícia do mercado imobiliário, que prossegue intensiva e rapidamente transformando a região. Sob a gestão da Subprefeitura da Lapa, a região objeto de estudo e do plano frustrado atesta transformações advindas da reestruturação produtiva do setor secundário, materializadas com o abandono das antigas instalações industriais (ver Figuras 1 e 2 e Mapa 1). O esvaziamento e deslocamento do setor secundário e plantas industriais para áreas próximas às saídas da cidade, contribuem para transformar a ocupação do solo junto a um significativo aquecimento do setor imobiliário na cidade e no vetor sudoeste da cidade. Conforme o Jornal "O Estado de São Paulo" (2011), o distrito de Vila Leopoldina atingiu, no período de 2004 a 2011, a cifra de 189, 1 milhares de metros quadrados construídos, consistindo na área da cidade que mais recebeu construções no intervalo de tempo considerado.

Deve-se chamar a atenção para a conduta da política urbana que, mediante a ausência da Operação Urbana que preconizava transformação visando à qualidade total da área, pauta-se na agilização das práticas do mercado imobiliário, estimulando a verticalização mediante venda de potencial adicional do direito de construir para os empreendimentos imobiliários. O sucesso obtido pela ação do mercado na área faz protelar qualquer outra forma de atuação do Poder Público e de resgate do plano engavetado, solapando-se a transformação global da região, que deveria assistir ao desenvolvimento de espaços públicos, sistemas de drenagem, equipamentos públicos e serviços e áreas de lazer coletivas, em detrimento do avanço da verticalização e de infraestrutura viária, recrudescendo conhecidas políticas urbanas de índole rodoviarista e de tom desenvolvimentista.

É possível observar também conflitos e flagrantes diferenças entre, as transformações projetadas pelo plano, e as realizações em curso decorrentes da ação de empreendedores imobiliários, com a aquiescência do governo municipal. $\mathrm{O}$ mesmo poder público que solicitou à equipe técnica competente um projeto urbano para a área alvo de OUC, a fim de intermediar intervenção urbana de amplo alcance, aquiesce com a transformação daquele espaço fundamentada na realização pontual de empreendimentos imobiliários, comerciais e residenciais, de médio e alto padrão. Além da prioridade dos empreendimentos imobiliários, o conflito é sugerido pela realização de infraestrutura viária que favorece a expansão imobiliária, preterindo outras ações que articulariam as dimensões viária, imobiliária e de espaço público.

O Projeto Urbano, que poderia ser o elemento integrador de instâncias e decisões parciais, parece sucumbir quase sempre à dinâmica da expansão imobiliária, permanecendo como ideal irrealizado. Esses descompassos verificados entre cidade planejada e real são o mote a alentar a mencionada pesquisa e debates críticos em torno do tema a que se dedica. 
FIGURAS 1 e 2 A região hoje e perímetro da OUC Vila Leopoldina-Jaguaré Mapa 1 Distritos de Vila Leopoldina e Jaguaré, São Paulo


FONTE SEMPla, 2003. 
MAPA 1 Localização dos distritos de Vila Leopoldina e Jaguaré, no Município de São Paulo

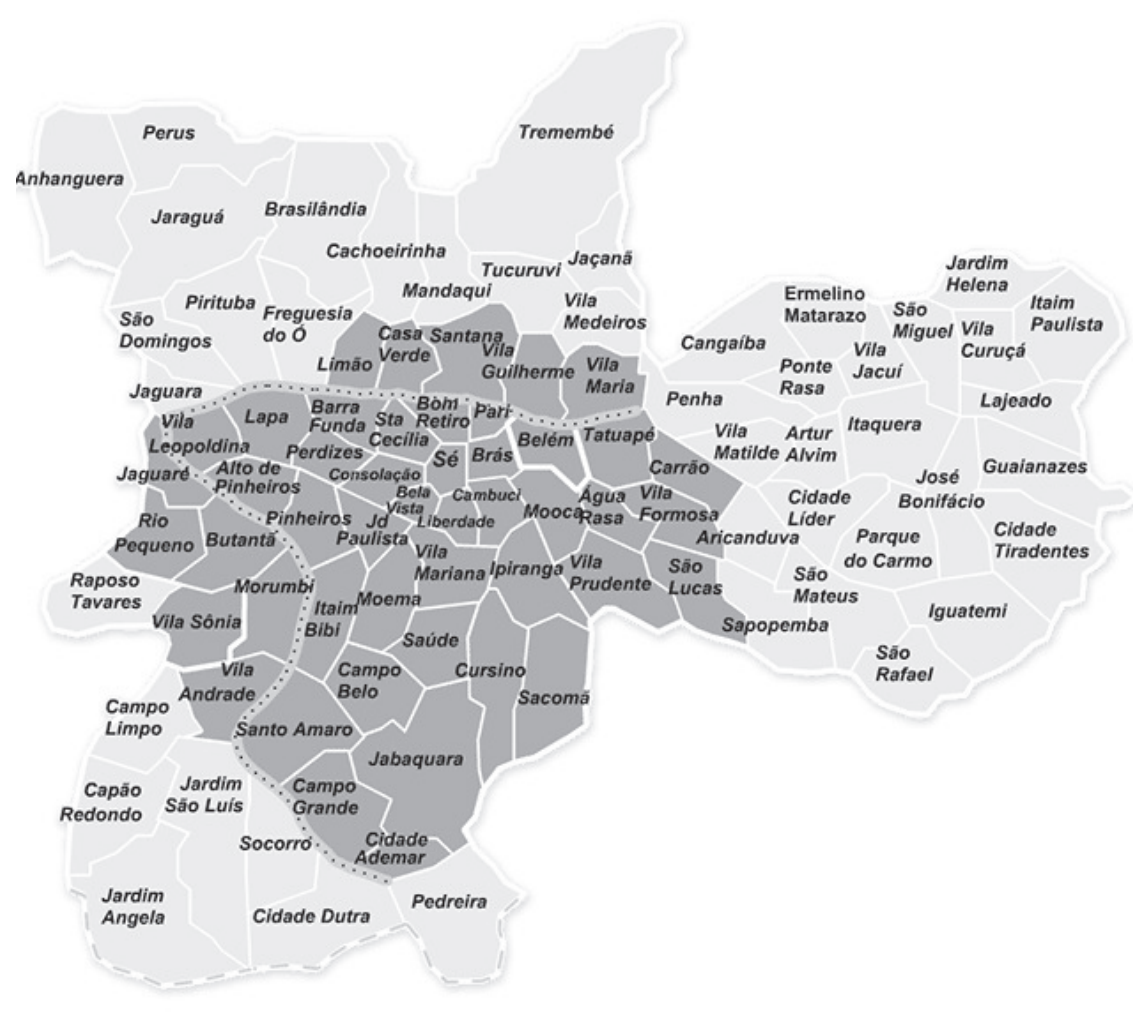

FONTE WWW.GOOGLE.BR

Projeto urbano e Operação Urbana: convergências necessárias O que é Projeto urbano? Que relaçóes o Projeto Urbano guarda com o instrumento da Operação Urbana?

A crise urbana advinda das transformaçóes produtivas, que conduziram de uma sociedade eminentemente industrial à de serviços globalizada a partir da década de oitenta do século passado, impóe desafios às metrópoles contemporâneas para o enfrentamento dos efeitos de desigualdades e exclusão gerados com a urbanização dispersa (Reis Filho, 2006). Urge articular as pré-existências às reconfigurações do espaço urbano, evidenciadas como vazios e áreas ociosas e degradadas, decorrentes de mudança de usos do solo. É preciso incorporar às soluçôes advindas do planejamento do território, demandas sociais fruto do aumento da pobreza e segregação.

O projeto urbano consagrou-se como reação ao planejamento de larga escala preconizado em períodos anteriores. $\mathrm{O}$ projeto urbano suscitou o debate da relação 
entre projeto e gestão estratégica e projeto e política urbana, fundamentado em normas e procedimentos reflexivos. Essa visão enunciou, como tese, a necessária definição de um conjunto de ações e instrumentos que considerem, tanto as potencialidades locais, como transformação do espaço e da sociedade contemporânea, a partir de uma lógica inclusiva (Ascher, 2010).

Os projetos urbanos deveriam, sob essa ótica, serem "iniciativas de renovação urbana concentradas em determinados setores da cidade" (Somekh \& Campos Neto, 2005 , p. 1), reunindo investimentos e intervenções de agentes públicos e privados, com base em um plano urbanístico. O plano deveria servir à mediação de demandas socioeconômicas e técnico políticas, visando o redesenho do espaço urbano e arquitetônico, fundamentados em normas específicas, articulações institucionais e gestão. Se conduzidos de forma a atender a lógicas e interesses setoriais, os projetos urbanos podem potencializar efeitos excludentes característicos da urbanização contemporânea (Alvim, Abascal \& Moraes, 2010). Caberia à administração pública a responsabilidade da "gestão da transformação", "[...] sendo que o poder público não deve desempenhar apenas função de 'guardião das regras', devendo dividir com a iniciativa privada a responsabilidade da concepção projetual total (Benévolo, 2007, p. .53).

O município no Brasil, a partir da Constituição Federal de 1988, desempenha papel primordial na conduta da política de desenvolvimento urbano e recentes análises evidenciam a complexidade advinda da descentralização e consolidação da sociedade de contratos, o que exige novas normas de conduta, legando aos diferentes atores públicos o dever de cooperar, obrigatória e inevitavelmente. Segundo Guerra (2002, apud Alvim, Abascal \& Moraes, 2010, p. 217) essa cooperação entre agentes diversos demanda e concede maior espaço ao processo decisório local, possibilitando inovações em políticas públicas, onde "entra em cena uma pluralidade de atores, de configuração e legitimidade social diversa e as 'negociações' adquirem nova visibilidade e legitimidade" (id., ibid. p. 218).

O projeto deixa, sob essa perspectiva, a exclusiva condição de desígnio acompanhado de desenho, alcançando novo status de ferramenta de análise e negociação. O resultado desse processo pode se manifestar ambíguo e, por sua complexidade e escala, o instrumento pode tanto acirrar a privatização ou contribuir para resgatar a essência pública da gestão urbana. A extrema complexidade de processos e problemas urbanos impede pensar no total abandono da regulação do Estado, admitindo-se a urgência da negociação e não somente regulamentação. Tal negociação é entendida como produção de consensos, teoricamente mediada por parcerias público-privadas, conduzindo à conciliação de atores diversos e garantindo o benefício coletivo em face da ação exclusiva do capital. Entretanto, essa "conciliação" pode ocultar um sentido de domesticação, ao evidenciar práticas empreendedoristas fundamentadas no acirramento da diferença e exclusão. A possibilidade de superar o aprofundamento da alienação da voz e do corpo social na produção do espaço urbano, reside em fazer do projeto urbano um instrumento de participação e governança, admitindo a existência de interesses coletivos, articulados em diferentes escalas, garantindo assim democracia e diversidade (Harvey, 2004). 
No Brasil, a promulgação da Constituição Federal de 1988, associada aos princípios de redemocratização, descentralização e implementação da política urbana em nível federal, amplia a competência local, possibilitando aos municípios a introdução de instrumentos contemporâneos e flexíveis de intervenção na cidade (Presidência da República, 1988). A Operação Urbana Consorciada (OUC) se define, nesse contexto, como instrumento para estabelecer diretrizes e meios para o desenvolvimento induzido, com base em um projeto urbano a partir da articulação entre agentes públicos e privados.

No entanto, em quase duas décadas de aplicação desse instrumento em São Paulo, os ganhos para a sociedade e ambiente construído são ainda poucos expressivos. Observam-se distintas situações, como omissão ou parcialidade na implementação de projetos urbanos, reforçando conflitos entre plano e cidade real, bem como sucessivas alterações ou sobreposições de propostas para novos projetos e investimentos, expondo as fragilidades das relações entre as dimensões técnica e política. Essas fragilidades revelam uma ação assincrônica e descompassada, que afeta também as áreas alvo ou objeto de intervenções urbanas concertadas (Alvim, Abascal \& Moraes, 2010).

Um planejamento urbano e estratégico não pode ser definido de maneira imediatista como urbanismo leviano (Ascher, 2010), mas a utilização de seus instrumentos para a realização de interesses e decisões setoriais vem afastando, no caso paulistano, a teoria da realidade. Do ponto de vista teórico, a premissa que planejar estrategicamente é servir ao mercado se revela apressada e equivocada, mas a prática brasileira e paulistana vem afirmando esse fenômeno como exploração de oportunidades e prioridade às forças econômicas hegemônicas, favorecendo ao capital e às grandes incorporadoras e construtoras. Revela-se o aprofundamento da clivagem entre teoria e realidade, afastando a prática do projeto e do plano dos princípios que norteiam o atendimento de demandas sociais.

Enquanto o urbanismo moderno fundamentava projetos com base em ordenamento e zoneamento ao definir densidades, atividades e gabaritos, o novo urbanismo defendido por Ascher (2010) se centra em objetivos e resultados, incentivando parcerias entre atores públicos e privados, a fim de realizar os objetivos a partir da ambição de eficiência. O projeto urbano, entendido como plano expresso em desenho agregador de qualidades arquitetônicas e ambientais, em tese, poderia integrar diversos atores, mediando à necessária complexidade ao evitar monofuncionalidades. Estimular a diversidade funcional, múltiplas centralidades e redes de transporte e mobilidade (id., ibid.) depende, no entanto, da política urbana e da disposição de contemplar a sociedade e o território em sua diversidade. Conferir protagonismo à governança e apoiar o planejamento do território como forma de enfrentar a agilidade com que o capital globalizado e financeiro hoje o desenha, materializando em ativos imobiliários a circulação financeira (Soros, 2002) é, pois, um dos pressupostos do "neourbanismo" e faz pensar em dispositivos e mecanismos de debate e negociação mais amplos, em meio à sociedade democrática.

As Operações Urbanas seriam, por definição, instrumentos de transformação estrutural de fragmentos da cidade, com base em gestão sinérgica entre o poder 
público e iniciativa privada, expressando-se por meio de projeto urbano (Montandon \& Souza, 2007). O instrumento das Operações Urbanas Consorciadas (evolução institucional das $\mathrm{OU}$ ) apresentaria complexidade e requinte suficientes para alcançar esses objetivos. A arrecadação de contrapartidas é, pois, um instrumento complementar para financiar obras públicas, infraestruturas, serviços e equipamentos, caracterizando as intervenções como articulação complexa do espaço urbano, uma vez que reverteriam dentro dos limites do perímetro em foco. Reconverteriam áreas subutilizadas, como as que foram ou são objeto de OUC, tais como a idealizada Vila Leopoldina-Jaguaré.

As Operações Urbanas seriam mecanismos opostos à livre atuação do mercado imobiliário e ações de cunho individualista, pautadas pela ambição de lucro, bem como estratégias de especificação do ambiente construído. Se as contrapartidas pagas se tornam, como no caso da área da OUC fracassada, mecanismos exclusivos de arrecadação, uma vez que os recursos obtidos pela negociação de Cepac se destinam a um Fundo Público Municipal e ficam à espera de reaplicação dispersa e voluntarista no território, perde-se a função conceitual originária, dando-se uso conservador a instrumentos que poderiam servir a políticas urbanas progressistas, tais como a promoção de uma cidade compacta evitando sua dispersão progressiva. Com esse desvirtuamento, as OUC parecem não desempenhar a máxima potencialidade transformadora e, os instrumentos de política urbana que nasceram vinculados a elas, servem a interesses privados, deixando de se voltar a uma cidade mais justa e de melhor qualidade ambiental. Os resultados quanto ao ambiente construído, obtidos mediante OU e OUC diferem, radicalmente, dos engendrados pela reprodução da lógica de mercado imobiliário, podendo alimentar o processo comparativo entre plano e realidade na área em estudo.

\section{A importância de um quadro crítico do instrumento da Operação Urbana Consorciada}

A elaboração de um quadro crítico da Operação Urbana Consorciada envolve o complexo embate entre as realizações do mercado imobiliário e as transformações por ele impostas ao ambiente construído e as propostas urbanísticas do poder público, evidenciando desencontros e assincronias, aprofundando a distância entre o projeto urbano e sua implementação. Sequer tendo saído das intenções, o interesse científico em um objeto como a Operação Urbana Vila Leopoldina-Jaguaré se centra na comparação entre o que o plano previra, em relação aos usos e padrões de densidade, verticalização e espaços públicos, e a prática que prioriza o uso residencial de médio e alto padrões, concentrado em formas de morar caracterizadas pelos empreendimentos residenciais verticais que proliferam.

A verticalização assistida se baseia em expansão da oferta residencial de classe média e alta guiada pela atuação do mercado imobiliário, apoiada na possibilidade de adensamento garantida pelo zoneamento (relação entre a verticalização, o coeficiente de aproveitamento e a área do terreno) e aplicação de instrumentos urbanísti- 
cos, estrategicamente escolhidos para garantir ao empreendedor uma verticalização rentável. As figuras 3 e 4 evidenciam o forte descompasso existente entre a forma de adensamento proposta no plano da OUC e o ambiente efetivamente construído.

O Projeto Urbano proposto pelo plano em 2003/04 propunha adensamento habitacional controlado quanto aos gabaritos praticados, e o concentrava principalmente na área que é hoje ocupada pela Central de Abastecimento Geral do Estado de São Paulo (Ceagesp). Propunha a remodelação do sistema viário e a execução de pontes já parcialmente em construção sobre os Rios Pinheiros e Tietê, para conectar a região a outras áreas e saídas da metrópole. Este complexo viário inclui novas ligações com o sistema Anhanguera - Bandeirantes ao norte da cidade (hoje em construção), assim como a expansão da Avenida Jaguaré e da Rua Alvarenga, e a construção de nova avenida paralela à Marginal, ligando a Avenida dos Remédios, a Lapa de Baixo e a Av. Marquês de São Vicente. Nesta OU, fato que se repete em outras em implementação, atende-se ao imperativo de remodelar as conexões estruturais da cidade, favorecendo acessos e escoamento de fluxos, para o que a abordagem infraestrutural é uma das condições primordiais e necessárias para o seu sucesso (Prefeitura Municipal de São Paulo/Sempla, 2003). No entanto, o plano se articula a um Projeto Urbano que desenhou a área como um todo, sinergicamente pensado em termos de infraestrutura, serviços, habitação de padrões diversos (incluindo Habitação de Interesse Social), comércio e espaços públicos.

Estas evidências sugerem que a prioridade de cumprimento de cronograma vem sendo conferida à infraestrutura e à expansão imobiliária, ações que substituem e antecipam as realizações de integração das dimensões viária, imobiliária e de espaço público, nas regiões alvo de Operações Urbanas. O Projeto Urbano que seria o elemento-chave articulador de instâncias e decisões parciais, ao integrar o fragmento ao tecido urbano, parece sucumbir quase sempre à expansão imobiliária, ficando aquém da realidade e expondo a face perversa de um procedimento de origem progressista.

O setor imobiliário veio se beneficiando, nos últimos cinco anos, de uma sólida capacidade de investimento decorrente da capitalização de construtoras e incorporadoras, resultado do crescimento econômico e investimento na construção civil voltada aos segmentos sociais mais favorecidos (Gaiarsa \& Monetti, 2007). A reprodução da dinâmica imobiliária, como forma de expansão da acumulação de capital, depende da disponibilidade de espaço e de sua apropriação pelo empreendedor (Harvey, 2005). No caso da área em estudo, apercebendo-se da disponibilidade de grandes áreas e glebas resultantes da desconcentração industrial de São Paulo nas décadas de 1980 e 90, vem se investindo na construção de edifícios residenciais novos.

Estes empreendimentos se caracterizam pela implantação de uma ou mais torres, ocupando o solo em substituição aos galpões industriais que daí se evadiram (vide figuras 5 e 6). Tal ocupação vem gerando um ambiente construído tradicional e conservador, ao privilegiar atividades que se revestem, quase que exclusivamente, de caráter monofuncional, reproduzindo o padrão do edifício isolado no lote. Trata-se, no entanto, de monofunção relativa, pois o uso residencial atrai outros, é 
bem verdade; no entanto, essa localização relativa de usos diversificados (comércio e serviços) acaba por ocorrer sem qualquer coordenação de conjunto, o que seria garantido pelo projeto urbano e consequente desenho, articuladores dessas atividades aos espaços públicos.

\section{FIgURAS 3 e 4 Ocupação proposta pelo Plano e resultado da dinâmica} imobiliária na região
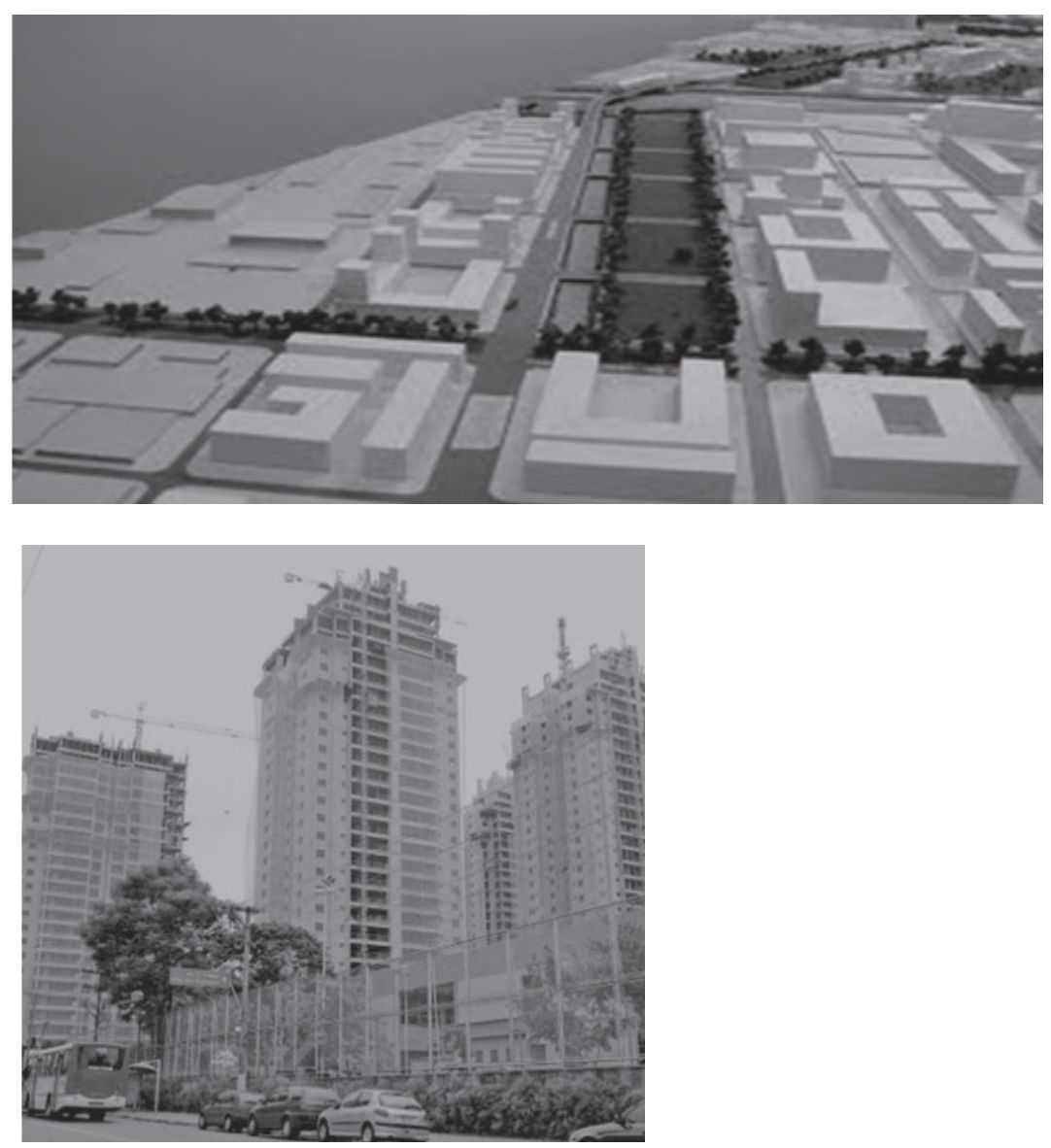

FONTES WWW.SKYSCRAPER.COM; FOTO DA PESQUISADORA DISCENTE GRISIELE ALMEIDA GUIMARÃES.

O mercado imobiliário paulistano se vale da verticalização proporcionada pela relação entre área do terreno (ao adquirir quantidades significativas de terra) e o índice urbanístico do coeficiente de aproveitamento. Dados obtidos na base cedida pela Empresa Brasileira de Estudos do Patrimônio (Embraesp, 2010) mostram empreendimentos aproveitando a disponibilidade de terrenos variando de 1.000 a 30.000 metros quadrados. A negociação do potencial adicional do direito de construir a partir 
de definição de estoques, em acordo direto entre empreendedor e poder público, consiste no impulso à prioridade desta prática de alcance parcial (Antenor, 2009).

Nos distritos de Vila Leopoldina e Jaguaré, a pesquisa em curso vem evidenciando que, com a aplicação do mecanismo descrito, a atuação do poder público municipal aprofunda o descompasso e as dificuldades de plena implementação dos instrumentos urbanísticos previstos no Estatuto da Cidade, fundamentando-se em ganho propiciado pela reprodução de empreendimentos imobiliários. Os mecanismos que reproduzem a expansão imobiliária e estão centrados nos ganhos que essa prática permite, inibem o alcance de novas configurações de espaço e equipamentos públicos, como também de habitação de interesse social, contribuindo para perpetuar o conservadorismo ao postergar a relação do instrumento urbanístico e do projeto urbano. Com este descompasso, os aspectos quantitativos da expansão imobiliária sobrepujam os qualitativos, relacionados aos efeitos do projeto em áreas-alvo de OUC.

A intensa verticalização e especialização em tipologias específicas podem ser verificadas com base em análise qualitativa dos empreendimentos imobiliários e outra quantitativa (estatística). Esta última análise pode ser realizada tomando por fundamento as categorias apresentadas pela base de dados fornecida à pesquisa pela Embraesp. A Empresa cedeu aos pesquisadores base atualizada de empreendimentos realizados na área de estudo, no intervalo de fevereiro de 2002 a fevereiro de 2010, cuja análise é apresentada na seção seguinte.

\section{Análise qualitativa: perfil de alguns empreendimentos na área da OU Vila Leopoldina-Jaguaré, padrões de ocupação e ambiente urbano}

A seguinte análise toma por base um conjunto de observações empíricas qualitativas, sistematizando os empreendimentos residenciais verticais no perímetro da OU Vila Leopoldina-Jaguaré ${ }^{3}$. Os registros possibilitaram observar algumas características comuns aos empreendimentos, como a presença de portarias ou guaritas que filtram o acesso de visitantes, e funcionam como elemento de segregação dos condomínios relativamente à rua. Os condomínios verticais que hoje pontuam a paisagem se apresentam, de forma geral, como condomínios fechados, protegidos por grades, muros, dispositivos de filtro de visitantes e acessos, e esquemas de segurança. Inserem-se no meio urbano de forma introvertida e isolada do espaço público, negando com esses artifícios qualquer relação com a rua. Por essa razão, investem em soluções de térreos e implantação cujo resultado é a introspecção espacial e, por conseguinte, de seus moradores. Muitos desses condomínios dispõem de equipamentos de lazer de uso coletivo nos térreos, sugerindo que os moradores possam substituir saídas e relacionamentos com o espaço público ao utilizarem tais equipamentos.

3 Para tanto, foram elaboradas fichas contendo as informações seguintes: nome do empreendimento, numeração na planilha de base Embraesp (2010), endereço, número de dormitórios, número de pavimentos, número de torres, área útil, área do terreno, número de unidades residenciais. Cada ficha apresenta também uma investigação realizada por meio do Google Street View, captando vista aérea e fotografias, que seguiram os critérios de registro de fachada, volumetria e relação com o espaço urbano, a rua e o entorno imediato. 
O bairro é ainda hoje ocupado por galpões industriais (ativos ou não) ou destinados aos serviços à produção industrial e comércio. Essa ocupação se faz acompanhar de uso residencial unifamiliar de baixa densidade, sendo possível que tal densidade resulte num padrão, herança do tipo de ocupação anterior, de natureza eminentemente industrial. Essas peculiaridades têm como resultado, frente à implantação atual dos condomínios verticais, um ambiente marcado por forte contraste entre as torres que vêm sendo construídas e o bairro tradicionalmente fabril, destinado ao uso residencial de classe média e média baixa.

É possível supor que essa contradição de usos e ocupação, industrial e pós-industrial, gere a percepção ao visitante de despreparo urbanístico da região frente à transformação recente, verificada com a implantação de condomínios verticais. Tal contraste é visível nas investigações realizadas, observando-se em muitos casos, a vizinhança ainda fabril dos condomínios residenciais que se inserem em meio a um ambiente urbano que revela ainda, traços da ocupação anterior.

A repetição tipológica que se verifica com a presença de padrões edilícios semelhantes, é reforçada ao se observar os empreendimentos mais recentes: há uma tipologia construtiva decorrente de planta com quatro ou duas unidades por andar, circulação central que se projeta na fachada, estabelecendo eixo de simetria que divide duas alas com sacada ou balcões em cada pavimento tipo. A mencionada simetria é demarcada pelo coroamento do edifício, como se percebe nas figuras 5 e 6. Mesmo em empreendimentos com mais de duas torres em terrenos de áreas superiores a $4.000 \mathrm{~m}^{2}$, nota-se a repetição desse padrão construtivo, contribuindo para defini-lo um tipo, e para um espaço urbano de enfática repetição e monotonia, contraditório frente às possibilidades da arquitetura contemporânea de criar um ambiente heterogêneo no que diz respeito ao edifício e sua relação com o entorno. Verifica-se também recorrentemente, confirmando o que foi anteriormente exposto, que as torres na maioria dos casos se implantam distantes da rua, e o espaço remanescente aos edifícios está ocupado por térreos elevados, contendo garagens e outros equipamentos de uso coletivo: salas de ginástica, salões de festas, etc.. Esse artifício é um dispositivo de isolamento das unidades residenciais relativamente à rua, solução que agrega especificidades veiculadas pelo mercado imobiliário como fatores de agregação de segurança e privacidade.

O padrão social a que se destinam os empreendimentos é predominantemente de classe média e média alta. Constata-se o padrão das construções pela uniformidade no tratamento dos materiais e acabamentos, bem como pela variação do número de torres relativamente à área útil das unidades e área dos terrenos. Quando o terreno e número de torres são menores, verificam-se menos unidades por andar e área útil maior; ao aumentar a área dos terrenos, verifica-se aumento no número de torres e diminuição das áreas úteis; entretanto, observa-se a presença de térreos generosos dotados de equipamentos de uso coletivo, qualidade que é um fator de 
valorização financeira do imóvel e atributo de agregação de valor e construção da imagem dos empreendimentos como um "condomínio clube" (Sampaio, 2010).

As tipologias construtivas e padrões de ocupação urbana na área, tal como explicitado, sinalizam tendências do mercado imobiliário que, inseridas em um contexto de aquecimento de demanda, ocorrem de forma extensiva e dispersa em diversos bairos da cidade, submetidos às mesmas condições de transformação de usos. Os novos empreendimentos verticalizados se pautam por atrativos mercadológicos, consolidando formas de ocupação segregada, sem integração com os espaços públicos e outras especificidades contextuais do bairro, replicando, assim, modelos de enclaves pontuais que negam a cidade, mas se apropriam da valorização simbólica do lugar.

\section{A atuação do mercado imobiliário na área-alvo da OU Vila Leopoldina- Jaguaré, de 2002 a 2010: uma análise estatística}

Nesta parte, realiza-se uma análise descritiva fundamentada na base Embraesp, que disponibilizou dados sobre empreendimentos imobiliários realizados nos distritos de Vila Leopoldina e Jaguaré, no intervalo de março de 2002 até março de 2010. Tais dados foram considerados como populacionais, uma vez que a Embraesp possui base bastante confiável do total de empreendimentos na área. Por meio de cálculo de medidas de tendência central, posição, variabilidade, forma da distribuição e da construção de gráficos e tabelas, busca-se resumir as informações disponíveis bem como conhecer melhor o comportamento das variáveis estudadas (Magalhães \& Lima, 2010).

Um dos gráficos utilizados foi o Boxplot em formato de caixa, com o nível superior dado pelo $3^{\circ}$ quartil e o nível inferior pelo $1^{\circ}$ quartil. A mediana é representada por um traço no interior da caixa e segmentos de reta são desenhados da extremidade da caixa até os valores máximo e mínimo que não sejam discrepantes. A representação gráfica através do Boxplot fornece, entre outras informações, a variabilidade e a simetria dos dados (Montgomery \& Runger, 2009). Para a realização da análise descritiva foi utilizado o programa estatístico Minitab (R) 16.

A análise partiu da categorização presente no cadastro da Embraesp, que forneceu as chaves para a sua realização ao discriminar as seguintes variáveis, qualitativas e quantitativas: nome do empreendimento, endereço, data de lançamento e de entrega, número de dormitórios, área útil, unidades por andar, número de pavimentos, total de unidades, área do terreno, construtoras/incorporadoras. O recorte de 2002 a 2010 é suficiente para indicar tendências e comportamento do mercado imobiliário, na área em estudo. Ao se observar a variável ano do lançamento na Fi-

gura 5, verifica-se uma maior incidência de lançamentos no intervalo 2006 a 2008. Este resultado pode ser interpretado considerando-se o boom imobiliário ocorrido nesse período, resultante do aquecimento da economia e capitalização das constru- 
toras. O total de lançamentos nesse intervalo é de 51,7\%.

Quanto ao número de dormitórios por unidade residencial, as porcentagens de lançamentos com 1, 2, 3 e 4 dormitórios foram respectivamente de 1,1\%, 16,8\%, $46,1 \%$ e $33,7 \%$. Verifica-se, portanto, uma predominância de apartamentos com 3 e 4 dormitórios (79,8\%). Tal configuração está de acordo com a predominância de empreendimentos voltados para a classe média alta e classe alta. Na base de dados aparecem 2,2\% dos lançamentos com 0,5 dormitórios (dois lançamentos). Tais lançamentos correspondem a uma situação atípica, na qual imóveis com $70 \mathrm{~m}^{2} \mathrm{de}$ área útil total podem dispor de diferentes arranjos funcionais e planta flexível, com dormitórios maiores e menores, de modo a condicionar o número de dormitórios à necessidade do comprador. Considerando-se o intervalo total de janeiro de 2002 a março de 2010, conforme apresentado nas figuras 6 e 7, predominam unidades residenciais maiores a $80 \mathrm{~m}^{2}$ de área útil (55,1\%), terrenos de mais de $2000 \mathrm{~m}^{2}$ $(59,6 \%)$, empreendimentos com mais de 15 pavimentos $(71,9 \%)$ e com mais de duas unidades por andar (80,9\%).

Conforme a Figura 8, pode-se notar que apartamentos com menos de $80 \mathrm{~m}^{2}$ têm, em sua maioria ( $80 \%$ do total), mais de 4 unidades por andar, e que somente para empreendimentos com residências de três e quatro dormitórios aparecem casos em que há até duas unidades por andar.

FIGURA 5 Gráfico para o ${ }^{\circ} \mathrm{e}$ porcentagem de lançamentos em função do ano

ANO DE LANÇAMENTO


$\mathbf{N}^{\circ}$ DE LANÇAMENTOS VS ANO

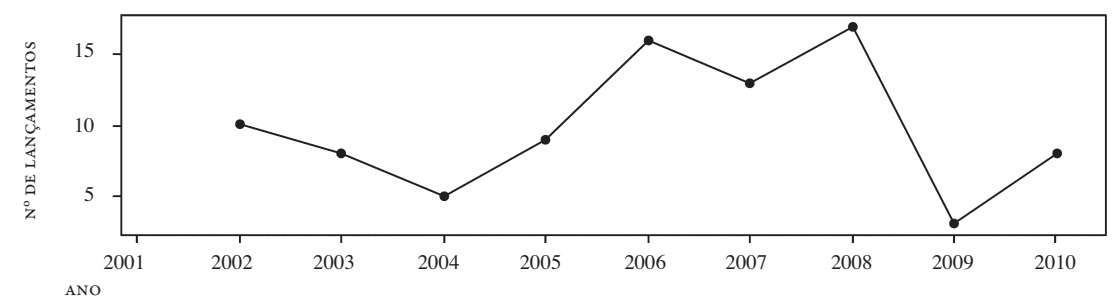

Fonte elaboraÇão própria, baseado em Empresa de Estudos do Patrimônio (Embrasep), 2010. 
FIGURA 6 Histograma e gráfico de setor para a área útil e área do terreno
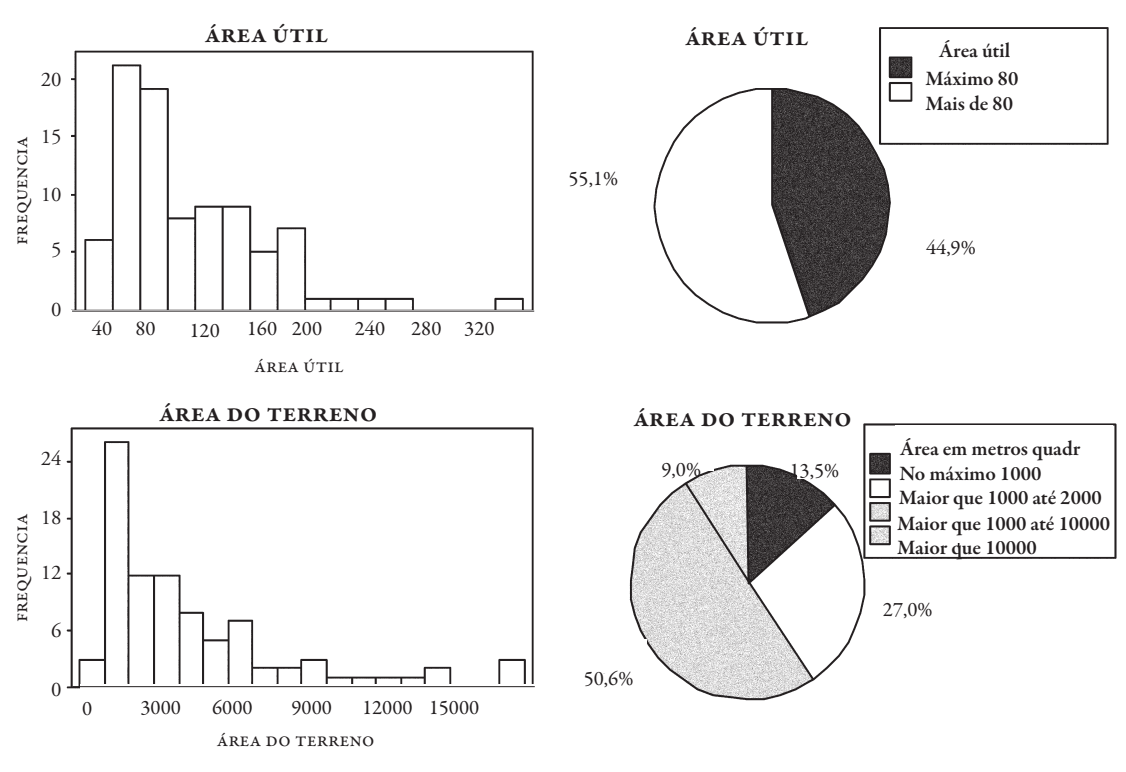

Fonte elaboraÇão própria, baseado em Empresa de Estudos do Patrimônio (Embrasep), 2010.

FIGURA 7 Histograma e gráfico de setor para número de pavimentos e de unidades por andar.
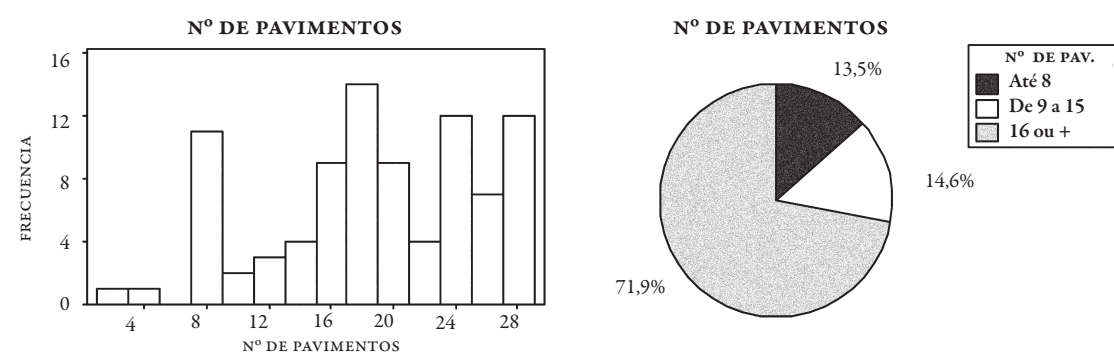

$14,6 \%$


Fonte elaboraÇão própria, baseado em Empresa de Estudos do Patrimônio (Embrasep), 2010. 
FIGURA 8 Gráficos de setor para no. de unidades por andar

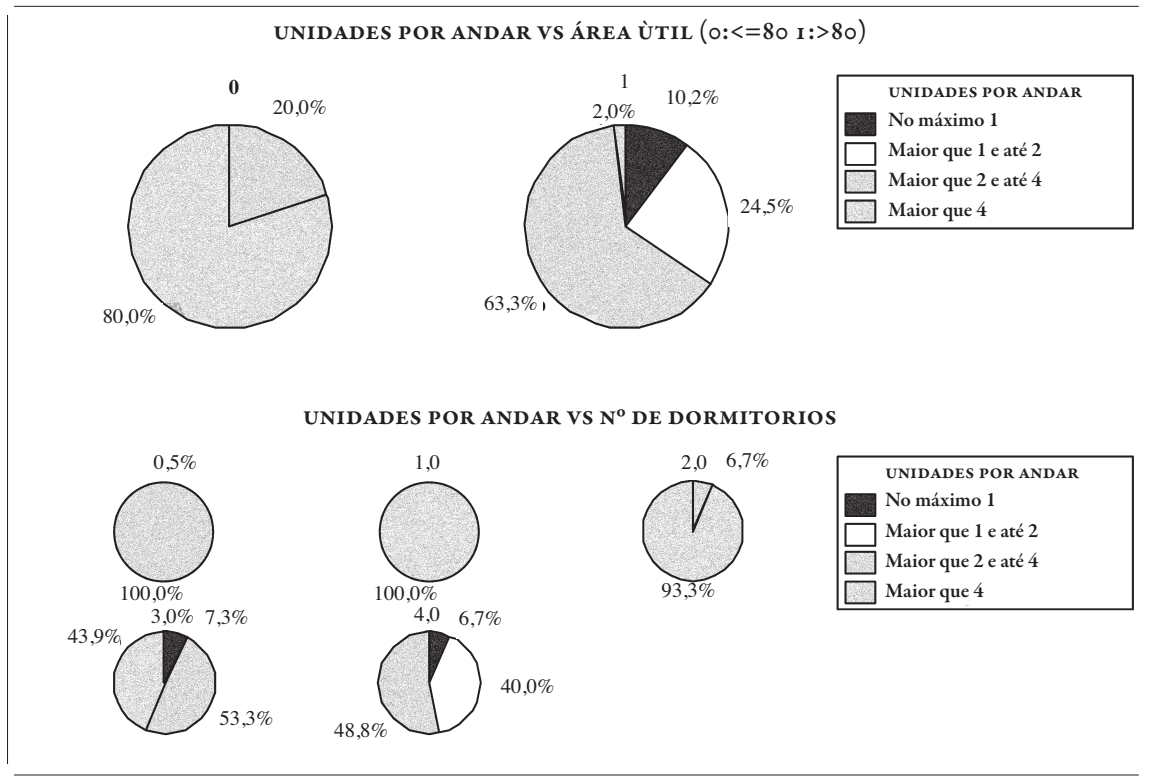

fonte elaboraÇão própria, baseado em Empresa de Estudos do Patrimônio (Embrasep), 2010.

Ao se cruzar a variável área útil com ano de lançamento, observa-se, na Figura 9 , a tendência a partir de 2009 de diminuição da área útil, para a faixa menor de $80 \mathrm{~m}^{2}$. Ou seja, observa-se que a área útil das unidades vem diminuindo, podendo indicar uma transição para um médio padrão de construção. Também a Figura 9 mostra que, a partir de aproximadamente $60 \mathrm{~m}^{2}$, já existem apartamentos com 3 dormitórios.

Ao mesmo tempo em que, conforme Figura 10, com o passar dos anos diminui a área útil, observa-se na Figura 10 que desde 2003 a maior incidência é de mais de 15 pavimentos, e em 2010, a totalidade dos lançamentos (até o mês de março) tem mais de 15 pavimentos. A partir de 2009, também verifica-se maior número de unidades por andar. A pesquisa, portanto, demonstra uma tendência de crescimento de empreendimentos com maior número de pavimentos e de unidades por andar, de modo que se disponibilize um maior número de unidades comercializáveis, mesmo em detrimento da área útil do apartamento, revelando assim, a lógica do mercado imobiliário de rentabilidade obtida com o crescimento das unidades. Por outro lado, tal lógica sugere que se atenda ao consumidor, que parece preferir empreendimentos com maior número de unidades a fim de minimizar as despesas condominiais. Observa-se uma maioria de empreendimentos com área de terreno maior que $2000 \mathrm{~m}^{2}$, o aumento do número de pavimentos e a diminuição da área útil das unidades, indicando a probabilidade de elevação do número de "condomínios clube" (empreendimentos que são assim denominados pelo mercado imobiliário, por disporem de área de lazer privativa no térreo). 
FIGURA 9 Bloxpot e Gráfico de setor para área útil e no. de dormitórios

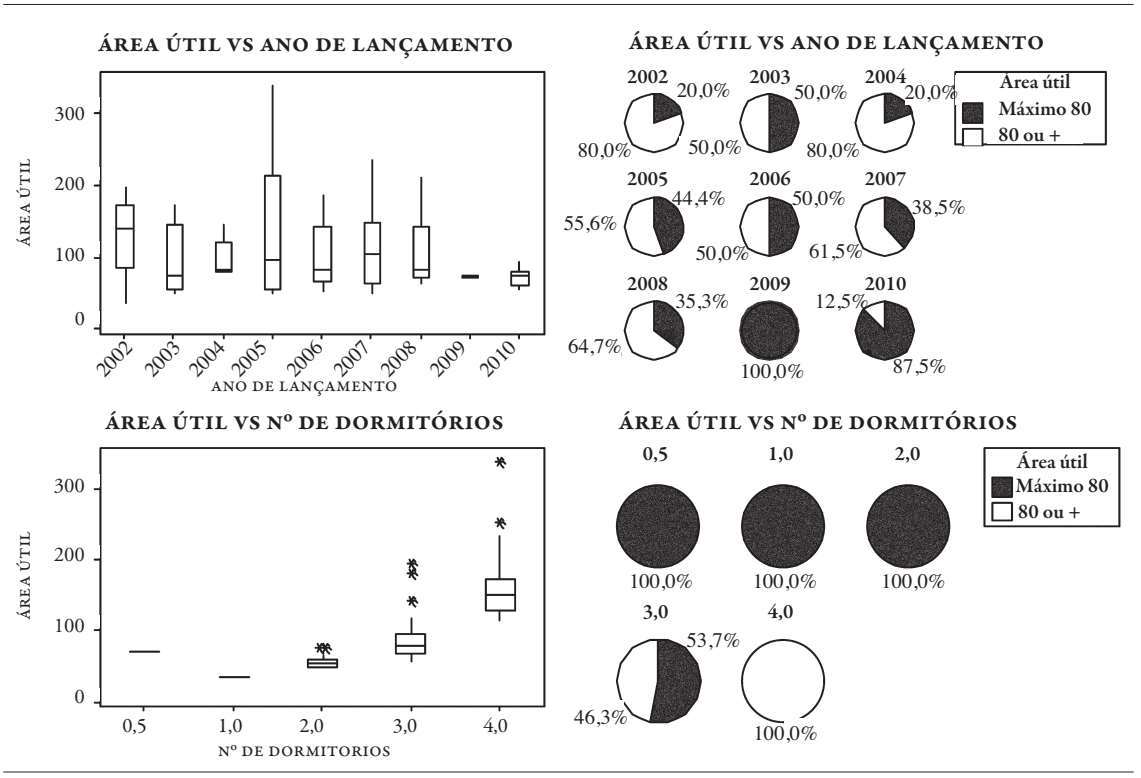

fonte elaboração própria, baseado em Empresa de Estudos do Patrimônio (Embrasep), 2010.

FIGURA 10 Área terreno, $\mathrm{n}^{\circ}$ de pavimentos e de dorms. e unidades por andar


fonte elaboraÇão própria, baseado em Empresa de Estudos do Patrimônio (Embrasep), 2010. 
A Tabela 1 apresenta algumas estatísticas descritivas para as variáveis: número de dormitórios, número de pavimentos, número de unidades por andar, número total de unidades, área útil e do terreno. Quanto maior o coeficiente de variação, maior a dispersão dos dados (Levine, Stephan, Krehbiel \& Berenson, 2008). Verifica-se que a área do terreno é a variável mais dispersa, seguida pelo número total de unidades, área útil e unidades por andar. Isto ocorre em função da disponibilidade dos terrenos na região estudada que apresentam áreas bastante heterogêneas.

TABELA 1 Estatísticas descritivas das variáveis da pesquisa

\begin{tabular}{|c|c|c|c|c|c|}
\hline VARIÁVEL & MÉDIA & DESVIO PADRÃO & $\begin{array}{c}\text { COEFICIENTE DE } \\
\text { VARIAÇÃO }\end{array}$ & MÍNIMO & MÁXIMO \\
\hline Número de dormitórios & 3,09 & 0,83 & 26,86 & 0,5 & 4,0 \\
\hline Número de pavimentos & 18,44 & 6,68 & 36,23 & 2,0 & 28,0 \\
\hline $\begin{array}{l}\text { Número de unidades por } \\
\text { andar }\end{array}$ & 4,37 & 1,89 & 43,24 & 1,0 & 10,0 \\
\hline Número total de unidades & 104,92 & 79,06 & 75,35 & 7,0 & 384,0 \\
\hline Área útil & 105,56 & 53,80 & 50,97 & 35,4 & 339,0 \\
\hline Área do terreno & 4171,00 & 4008,00 & 96,09 & 70,0 & 17279,0 \\
\hline
\end{tabular}

FONTE ELABORAÇÃO PRÓPRIA.

Analisando-se a base Embraesp, verifica-se diversidade de construtoras e incorporadoras, sendo recorrente a coincidência entre incorporadora e construtora. Como tendência geral pode-se dizer que, no recorte considerado da pesquisa, vem se modificando o padrão dos empreendimentos oferecidos na área, transitando de alto para um médio padrão. A análise dos dados possibilita dizer que ainda existem lançamentos pontuais de alto padrão acontecendo. Esta situação aponta que, como se observou nos gráficos anteriores, terrenos de menor área vêm sendo utilizados para empreendimentos com 3 ou 4 dormitórios por unidade residencial e índices maiores de verticalização. Verifica-se ainda a possibilidade de presença dispersa de empreendimentos de padrão diferenciado, com menos torres e menos unidades residenciais, indicando taxas condominiais maiores, destinados a estratos sociais de maior poder aquisitivo.

A diversidade de padrões, a tendência de maior verticalização, bem como o maior número de unidades residenciais e menor área útil, demonstram uma ação do mercado imobiliário de máximo aproveitamento das oportunidades, impondo padrões de ocupação e desenvolvimento centrados no produto arquitetônico mercadológico.

Os processos de verticalização na área da OU espelham valorizações imobiliárias significativas e o alto nível de competitividade desta região, no contexto do boom imobiliário recente da Região Metropolitana e do Município de São Paulo. As tabelas a seguir expõem a evolução dos preços do metro quadrado de área útil, tanto na região de Vila Leopoldina e Jaguaré como no Município e Região Metropolitana de São Paulo. Ao comparar as evoluçóes, verifica-se que o preço do metro quadrado, assim definido em Vila Leopoldina, distrito paulistano em que se observa a maior con- 
centração de verticalização, conforme anteriormente mencionado no caso de apartamentos de 2 dormitórios, foi, em 2010, ligeiramente inferior aos desempenhados no Município de São Paulo e superior ao da Região Metropolitana. Para apartamentos de 3 dormitórios, os valores em 2010 em Vila Leopoldina são inferiores aos praticados no Município, mas superiores aos da Região Metropolitana, apresentando-se no entanto, em ambos os casos exemplificados, próximos às faixas de valor recorrentemente praticadas no período enfocado. Embora os patamares de valor sejam relativamente altos nos distritos contidos no perímetro da frustrada Operação Urbana, verifica-se estabilidade de preços, que pode ser compreendida, por hipótese, pelo estado de degradação no qual a região se encontrava e a inexistência de melhorias urbanísticas e ambientais e estagnação do ambiente construído total, apesar da intensiva dinâmica do mercado imobiliário que fez com que os valores, de modo geral, se aproximassem do restante do município e da região metropolitana.

Os valores do metro quadrado em Vila Leopoldina excedem os de Jaguaré, o que pode se explicar pela proximidade relativa do primeiro distrito do bairro de Alto de Pinheiros, muito valorizado, apresentando $\mathrm{R} \$ 7.384,00$ por metro quadrado de área útil ${ }^{4}$. O valor superior de Vila Leopoldina se explica ainda pela possibilidade de acesso em automóvel, e a pé, de muitos pontos do bairro ao Parque Villa Lobos, equipamento público de alta qualidade ambiental. Jaguaré, no entanto, é um distrito bem mais carente de infraestrutura, apresentando ainda expressiva área de favela.

Tabela 2 Evolução Preços/m² de Área Útil (Reais), jan. de 2008 a set. de 2011

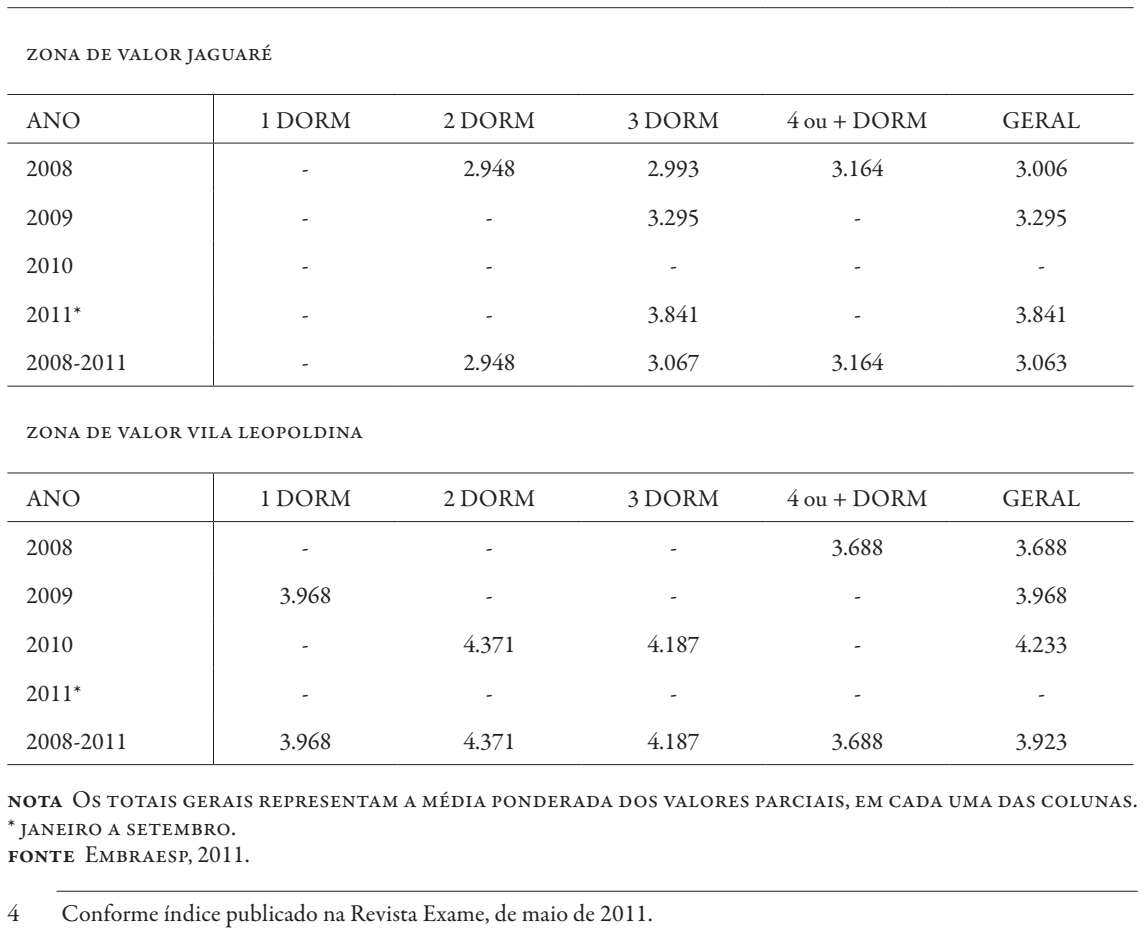


tabela 3 Preços/m² de Área Útil (em Reais), 2008 a 2010, Município e Regiáo Metropolitana

\begin{tabular}{|c|c|c|c|c|c|c|c|c|c|}
\hline \multicolumn{5}{|c|}{ MUNICÍ́to de SÃO PAULo (MSP) } & \multicolumn{5}{|c|}{ REGIÃO METROPOLITANA DE SÃo PAULO (RMSP) } \\
\hline \multicolumn{5}{|c|}{$\mathrm{PREÇO} / \mathrm{M}^{2}(\mathrm{R} \$)$} & \multicolumn{5}{|c|}{$\mathrm{PREÇO} / \mathrm{M}^{2}(\mathrm{R} \$)$} \\
\hline $\begin{array}{l}N^{\circ} \text { Dorm } \\
\text { Ano }\end{array}$ & 1 & 2 & 3 & $4 \mathrm{ou}+$ & $\begin{array}{c}\text { No Dorm } \\
\text { Ano }\end{array}$ & 1 & 2 & 3 & $4 \mathrm{ou}+$ \\
\hline 2008 & 3.189 & 2.473 & 3.085 & 4.455 & 2008 & 3.185 & 2.320 & 2.791 & 4.039 \\
\hline 2009 & 4.218 & 3.049 & 3.522 & 4.968 & 2009 & 4.218 & 2.706 & 3.218 & 4.761 \\
\hline 2010 & 7.243 & 4.367 & 4.773 & 6.543 & 2010 & 6.526 & 3.541 & 4.098 & 5.625 \\
\hline
\end{tabular}

FONTE Relatório Embraesp anUal 2010.

\section{Considerações finais}

O artigo possibilitou compreender que a área alvo da OU Vila Leopoldina-Jaguaré em São Paulo, vem sendo transformada por padrões arquitetônicos e urbanísticos ditados pela reprodução da lógica de oportunidades, praticada pelo mercado imobiliário e propiciada pelo poder público municipal. A situação encontrada permite indicar, como tendência, a ocupação do solo por empreendimentos predominantemente residenciais, de médio e alto padrão, caracterizados por condomínios verticais que pregam vantagens advindas de segregação relativa à rua e ao bairro. Além de problemas decorrentes dos padrões recentes de ocupação, a área permanece a reboque da presença da Ceagesp, contando com problemas causados pelo movimento de caminhões e procedimentos de estocagem e embalagem de produtos comercializados por aquele entreposto, além de problemas de drenagem e descuido ambiental.

O discurso veiculado pela publicidade, de que a região afetada por sérios desequilíbrios é um lugar aprazível e valorizado para residir e que as formas do habitar propaladas por condomínios fechados são atuais e de gosto generalizado, reforça a adoção do valor de recusa da relação entre edilícia e espaço público, justificando o total descompasso entre plano e mercado imobiliário. A situação prossegue, pois o poder de mediação do Estado, como o agente que hoje determina os índices de potencial adicional do direito de construir e estoques, é utilizado para perpetuar o modelo conservador e patrimonialista de planejamento, com políticas que priorizam a ação do mercado imobiliário e estancam outras práticas, como poderiam ser as OUC e intervenções decorrentes de projetos urbanos.

A ação oportunista do mercado imobiliário apoiada por atores públicos revela a existência de reprodução das mencionadas práticas conservadoras, perpetuando interesses restritos. Tal cooptação de interesses, de forma a deixar plano e projeto urbano engavetados, sugere que os principais agentes produtores do espaço urbano 
não são afeitos a uma transformação da ambiência encontrada na região. Equivale dizer que, em São Paulo, a aplicação de instrumentos urbanísticos como a Operação Urbana, voltados a equacionar a qualidade total do ambiente construído, hoje consolidados e reconhecidos em diversos países do mundo, vem se atrelando a opções políticas e embates de poder que menosprezam o Plano Diretor e apequenam esforços técnicos, até então realizados no sentido de direcionar as transformações urbanas previstas.

Constata-se desperdiçada a oportunidade para a cidade poder transformar uma área em processo patente de mudança de uso e degradação, a partir da aplicação do instrumento da Operação Urbana Consorciada associado a um projeto urbano capaz de coordenar as transformações da edilícia e do espaço público de maneira sincronizada e sinérgica. CEURE

\section{Referências bibliográficas}

Alvim, A. T. B., Abascal, E. H. S. \& Moraes, L. G. S. de (2010). Operação Urbana Consorciada e Projeto Urbano em São Paulo: Limites e Desafios. Anais do I Encontro Nacional, da Associação Nacional de Pesquisa e Pós-Graduação em Arquitetura e Urbanismo. Simpósio Temático: Projetos urbanos e a reinvenção do espaço-mundo na cidade contemporânea. Rio de Janeiro: Universidade Federal do Rio de Janeiro (UFRJ).

Antenor, N. M. T. (2009). A aplicação da Outorga Onerosa do Direito de Construir em São Paulo. São Paulo: Prefeitura do Município de São Paulo. Disponible en http://www.cidades.gov.br.

Ascher, F. (2012). Os novos princípios do urbanismo. São Paulo: Romano Guerra.

Benévolo, L. (2007). A cidade e o arquiteto. São Paulo: Estação Liberdade.

Castro, L. G. R. (2006). Operações urbanas em São Paulo: interesse público ou construção especulativa do lugar? Tese de Doutoramento. Faculdade de Arquitetura e Urbanismo, Universidade de São Paulo (FAU USP).

Diniz, C. C. (1996). Reestruturação econômica e impacto regional: o novo mapa da indústria brasileira. Revista Nova Economia, 6(1), 77-103.

Empresa Brasileira de Estudos de Patrimônio (Embraesp). (2010). Base de dados Empreendimentos Imobiliários em Vila Leopoldina e Jaguaré, de 2000 a 2010. São Paulo: Autor.

Gaiarsa, C. M. \& Monetti, E. (2007). CEPACs e Outorga Onerosa. Uma análise Comparativa. Trabalho apresentado no VII Seminário Internacional da Lares. São Paulo, 25-6 de outubro.

Harvey, D. (2004). Espaços de esperança. São Paulo: Edições Loyola.

Levine, D. M., Stephan, D. F., Krehbiel, T. C. \& Berenson, M. L. (2008). Estatística: Teoria e Aplicações - Utilizando Microsoft Excel Português. 5a . ed. Rio de Janeiro: LTC.

Magalhães, M. N., Lima, A. C. P. (2010). Noções de Probabilidade e Estatística. 7ª ed. São Paulo: Editora da Universidade de São Paulo (Edusp).

Ministério das Cidades (2009). Operações Urbanas. Anais do Seminário França-Brasil/Ministério das Cidades. Brasília: Autor.

Montandon, D. T. \& Souza, F. F. de (2007). Land Readjustment e Operaçôes Urbanas Consorciadas. São Paulo: Romano Guerra. 
Montgomery, D. C. \& Runger, G. C. (2009). Estatística Aplicada e Probabilidade para Engenheiros. $4^{\mathrm{a}}$ ed. Rio de Janeiro: LTC.

O Estado de São Paulo. Verticalização chega ao limite em 21 distritos de São Paulo. Cidades/Metrópoles, 23 de novembro de 2011, p. C8.

Prefeitura Municipal de São Paulo. Plano Diretor Estratégico do município de São Paulo: PDE 2002 2012, Lei Municipal no 13.430 de 2002. Diário Oficial da Cidade de São Paulo, [14/09/02, Folha 1], 2002.

Prefeitura Municipal de São Paulo/Secretaria Municipal de Planejamento (Sempla). (2003). Operação Urbana Vila Leopoldina-Jaguaré. Edital de Contratação, Termos de Referência e Primeira Etapa do PRIOU - Caracterização do Território. São Paulo: Sempla.

Prefeitura Municipal de São Paulo (2011). Outorga Onerosa. Entenda a Outorga Onerosa Direito de Construir. Disponible en http://www.prefeitura.sp.gov.br/cidade/secretarias/desenvolvimento_urbano/urbanismo/index.php?p=1393.

Presidência da República. Constituição da República Federativa do Brasil de 1988. Disponible en http://www.planalto.gov.br/ccivil_03/constituicao/constitui\%C3\%A7ao.htm, Acesso em: setembro de 2011.

Presidência da República. Estatuto da Cidade (Lei Federal no 10.257/2001). Disponible en http:// www.planalto.gov.br/ccivil_03/leis/LEIS_2001/L10257.htm.

Reis Filho, N. G. (2006). Notas sobre a urbanização dispersa e novas formas de tecido urbano. São Paulo: Via das Artes.

Revista Exame. "A maior alta do mundo". Edição 992, maio de 2011.

Ribeiro, L. C. de Q. \& Cardoso, A. (1992). O solo criado como instrumento da reforma urbana: uma avaliação do seu impacto na dinâmica urbana. Ensaios FEE (Porto Alegre), 13(1), 370-381.

Sampaio, G. B. D. do A. (2010). Condominios Verticais Residenciais na cidade de São Paulo (20002008): Condominios-clube. Dissertação de Mestrado, Programa de Pós-Graduação em Arquitetura e Urbanismo da Universidade Presbiteriana Mackenzie, São Paulo.

Secovi (Sindicato das Empresas de Compra, Venda, Locação e Administração de Imóveis Residenciais e Comerciais de São Paulo). (2010). Secovi São Paulo, Geosecovi. Disponible en http:// www.secovi.com.br/index.php.

Smith, N. (2006). A gentrificação generalizada: de uma anomalia local à "regeneração" urbana como estratégia urbana global. En: C. Bidou-Zachariasen (Org), De volta à cidade. São Paulo: Annablume.

Somekh, N. \& Campos Neto, C. M. (2005). Desenvolvimento local e projetos urbanos. Arquitextos (São Paulo), 05.059, Vitruvius, 2005. Disponible en http://www.vitruvius.com.br/revistas/read/arquitextos/05.059/470.

Soros, G. (2002). Globalização. Rio de Janeiro: Campos. 